\title{
Emigruojančio akademinio jaunimo socialiniai ryšiai formuojant darbo ir edukacinès paieškos strategijas
}

\begin{abstract}
Straipsnyje nagrinëjami socialiniai ryšiai igalina individą sukurti tarpasmeninių ir institucionalizuotų santykių tinklą. Šie ryšiai itin svarbūs tiriant akademinio jaunimo emigraciją formuojančias darbo ir edukacinès paieškos strategijas, siekiant asmeninių tikslų bei naudos.
\end{abstract}

Raktiniai žodžiai: akademinis jaunimas, socialiniai ryšiai, emigracija, edukacinè ir darbo paieškos strategijos.

Social ties being analysed in the article enable individuals to create a network of interpersonal and institutionalised ties, which are particularly important examining the strategies for the search of jobs and education of academic students in order to attain personal goals and benefit.

Keywords: academic students, social ties, emigration, strategies for job-searching and education-searching.

JEL Classifications: F22/I20/J61.

\section{Ivadas}

Socialinių ryšių, išryškinančių individų kooperaciją, fenomenas yra esminis socialinių ir elgsenos mokslų (psichologijos, sociologijos, politologijos, vadybos ir kt.) interesas, o jo svarba pabrèžiama socialinio kapitalo ir socialinio tinklo sampratose bei dažniausiai siejama su mokslininkų P. Bourdieu (1977), J. Coleman (1988), R. Putman (1993) darbais.
Socialinio kapitalo sampratoje socialiniai ryšiai išryškinami kaip suteikiantys naudingos informacijos, paramos, vertinami kaip faktiniai ir potencialūs ištekliai, racionalūs ar tikslingi veiksmai, individu normos ir vertybès, galimi kaip ištekliai tam tikrame socialiniame kontekste (Bourdieu, 1977; Coleman, 1988; Portes, 1998; Lin, 2001). Svarbiausia socialinio kapitalo charakteristika - konvertabilumas, kuomet kapitalas paverčiamas ị kitas jo rūšis

Nida KVEDARAITÉ - dr. doc., socialiniai mokslai (edukologija); KTU Panevėžio institutas. Adresas: Nemuno g. 33, Panevèžys; tel./faks.: 0037045 570030; el. paštas: nida.kvedaraite@ktu.lt. Mokslinių interesų sritys: besimokanti organizacija, žmogiškujuų išteklių vadyba, jaunimo užimtumas, judumas.

Aušra REPEČKIENĖ - dr. doc., technologijos mokslai (chemijos inžinerija); KTU Panevėžio institutas. Adresas: Nemuno g. 33, Panevėžys; tel./faks.: 0037045 570030; el. paštas: ausra.repeckiene@ktu.lt. Mokslinių interesų sritys: jaunimo užimtumas, judumas, žmogiškụjų išteklių vadyba, kultūrinès ịvairovès studijos.

Rasa GLINSKIENE - dr. doc., socialiniai mokslai (ekonomika); KTU Panevėžio institutas. Adresas: Nemuno g. 33, Panevéžys; tel./faks.: 0037045 570030; el. paštas: rasa.glinskiene@ktu.lt. Mokslinių interesų sritys: jaunimo užimtumas, judumas, rinkotyra. 
(pvz., ekonominị, žmogiškąjî), ypač ì finansini (Palloni ir kt., 2001). Be to, socialinis kapitalas apibrèžiamas, kaip ryšiai tarp žmonių: socialiniai tinklai ir iš jų kylančios abipusiškumo normos bei pasitikejjimas ir patikimumas (Putman, 1993), yra nevienalytis. Ši samprata atkreipia dèmesi i tai, kad socialinis kapitalas nors ir sunkiai apčiuopiamas, dideja naudojamas ir mažejja nenaudojamas, nes glūdi individų santykių struktūroje - socialiniuose tinkluose.

Socialinis tinklas įvardijamas kaip tam tikra socialinès struktūros forma, apibrèžianti juose dalyvaujančių individų socialinius ryšius, nusistovejusią elgseną ir socialinès tvarkos modelius (Schweizer, White, 1998). Individas (grupè) gali turèti įvairių socialinių ryšių (pvz., šeiminių, draugystès, bendradarbių, verslo, migrantų ryšiai ir kt.) ir tik jam (grupei) būdingą socialinị tinklą. Priklausomai nuo konteksto, socialiniu tinklų tipai gali ịvairuoti pagal lygị (makro, mezo, mikro), krypti (horizontalūs, vertikalūs), ittrauktị (ịtraukiantys, atribojantys), formalumą (formalūs, neformalūs), ryšių stiprumą (silpni, stiprūs, nedalyvaujantys), homogeniškumo požymį (susiejantys, sujungiantys), atvirumą (uždari, atviri) (Granovetter, 1983; Bourdieu, 1986; Scott, 2001; Hanneman, 2001). Giminystès, draugystès, kolegiški ar kaimynystès ryšiai padeda individams, jų grupèms per socialinius tinklus gauti naudos, rasti informacijos, surasti ar paveikti asmeni, pasinaudoti tik jiems prieinamais ištekliais ir galimybèmis (Mitchell, 1969; Coleman, 1988; Putnam, 1993; Lin, 2001). Be to, socialinis tinklas, kaip komunikacijos forma ir metodas, gali būti naudojamas vertinant ir individų mobilumą (Mitchell, 1969).

Socialinių ryšių analizè, plačiai taikoma socialiniuose moksluose, vis dažniau pasitarnauja ir kaip metodologinè prieiga migracijos tyrimuose, nagrinejant diasporas, transnacionalinius ryšius, migrantų tinklus. Pastarosiose studijose postūmị davè migracijos tinklo teorijos taikymas, aiškinantis migruojančiojo asmens ir jo šeimos, draugų, pažistamų ryšius, apimančius keitimąsi informacija, finansinę paramą, pagalbą randant darbą, būstą, dalijantis patirtimi ir pan. tikslo šalyje (Massey ir kt., 1993). Migracijos tinklo ryšiai vertinami kaip socialinis kapitalas, kuriame kinta individų nuostatos ir vertybès, o tinklo plètra tampa viena iš priežasčių, lemiančių migraciją, nepaisant ją sukèlusių priežasčių. Visgi, migracijos tinklų teorija nepakankamai paaiškina migracijos motyvus (Ryan ir kt., 2008), o socialinių tinklų sąvokos panaudojimas yra paviršutiniškas, vartojamas kaip aprašomoji metafora ir nepakankamai pagrindžiamas teoriškai (Vertovec, 2003). Todèl, kompleksinei migracijos reiškinių analizei pasitelkiama socialinių tinklų koncepcija, kurios vienas pagrindinių argumentų yra susijęs su teiginiu, kad migracija nèra individualus, o veikiau socialinis kolektyvinis sprendimas, iprasmintas daugelio heterogeniškų socialinių tinklų (Palloni ir kt., 2001).

Socialinių tinklų koncepcijai, socialinių tinklų analizès būdų ir jų taikymo migracijos studijose daug demesio skyrè ir Lietuvos mokslininkai: A. Sipavičienè (2006), A. Maslauskaitè ir V. Stankūnienè (2007), I. Gečienè (2009), J. Bučaitè-Vilkè, V. Rosinaitè (2010). Socialinio kapitalo vaidmeni išsimokslinusių žmonių migracijoje nagrinèjo D. Antinienè ir kt. (2004), A. Kazlauskienè, L. Rinkevičius (2006b), A. Repečkienè, N. Kvedaraitė (2011). Autorių darbuose išryškejja nuostata, kad emigracijoje vienas esminių traukos veiksnių priimančioje šalyje yra tarpasmeniniai individo santykiai, paremti giminyste, draugyste ar kilme. Migrantų tarpasmeniniai ryšiai sukuria „saviškumo“ jausmą, 
padeda jiems prisitaikyti ir įsitraukti $\mathfrak{i}$ naują visuomenę (Bučaitè-Vilkè, Rosinaitè, 2010). Santykiai, paremti šeimos ar giminystès ryšiais, padeda individui spręsti kasdieninio gyvenimo problemas, tačiau pagrindinis tokių santykių vaidmuo - sumažinti įvairius kaštus (piniginius, psichologinius) ir riziką susijusią su emigracija (Maslauskaitè, Stankūnienè, 2007). Institucionalizuoti ryšiai apima santykius viešoje erdveje, kurie yra „nematomi“, tačiau reikšmingi individo gyvenime: jie gali suteikti priejimą prie ịvairių materialinių, informacinių ir kitų išteklių. Socialiniais ryšiais kuriamas kapitalas igalina emigracijos procese dalyvaujantị individą sukurti tarpasmeninių socialinių santykių tinklą, kurie padeda realizuoti ekonominius, socialinius tikslus ar didinti finansinị kapitalą.

Pastaruosius keletą metú Lietuvos žiniasklaidoje bei mokslinèje literatūroje dažnai diskutuojama apie nepasitenkinimą šalies, kurioje gyvenama, socialinėmis, ekonominemis, o kartais ir politinėmis, kultūrinėmis sąlygomis, skatinančiomis migracijos srautų intensyvejjimą. Šalies gyventoju migracija dažniausiai siejama su ekonominiais poreikiais, pažymint, kad emigracijos procesą lemia ịvairūs veiksniai, pasireiškiantys kaip išstumiamieji arba pritraukiamieji ir formuojantys dabartinès visuomenès migracines nuostatas. Tačiau, ypatingai didelị susirūpinimą kelia jaunų žmonių, ypač aukštųjų mokyklų studentų bei absolventų emigracija i ekonomiškai pajègias ir patrauklias šalis, kuri įvardijama kaip sudètinga ir kompleksiška problema (Merkys ir kt., 2004; Kazlauskienė, Rinkevičius, 2006a; Repečkienė ir kt., 2009a). Šiame straipsnyje vartojama akademinio jaunimo sąvoka apibūdina aukštųjų mokyklų (universitetų ir kolegijų) studentus, studijuojančius laipsni suteikiančiose studijose. Dabartinès lietuvių kalbos žodyne (2006) akademinio jaunimo sąvoka atskleidžia jaunimo priklausymą aukštajai mokyklai. Taigi, galima teigti, jog žodžių junginys aukštuju mokyklų (universitety ir kolegiju) studentai bei sąvoka akademinis jaunimas gali būti vartojami kaip sinonimai.

Analizuojant akademinio jaunimo emigracijos priežastis, išryškejja motyvai, lèmę apsisprendimą išvykti dirbti ị pasirinktą užsienio šalį, kurie yra ne tik ekonominio, bet ir asmeninio pobūdžio. Tai atskleidžia socialinių santykių, grindžiamų abipusio pasitikejjimo pagrindu tarp emigruojančių individų (šiuo atveju - akademinio jaunimo), svarbą ir išryškina mokslinę problemą, kurią detalizuoja šie probleminiai klausimai: ar individu emigracinei patirčiai turi ịtakos jų ryšiai su šeima, giminèmis, draugais, kolegomis ar pažistamais? Kaip tarpasmeniniai ir institucionalizuoti ryšiai vertinami emigruojančiu individų darbinimosi/mokymosi paieškos strategijose?

Akademinio jaunimo socialiniai ryšiai emigracijos procesuose yra mažai nagrinèta sritis šalies mokslinių tyrimų erdveje, todèl šio tyrimo objektu pasirinkti emigruojančių aukštųjų mokyklų studentų socialiniai ryšiai.

Tyrimo tikslas - atskleisti emigruojančio akademinio jaunimo socialinius ryšius darbo ir edukacinès paieškos strategijose, tiriant Lietuvos aukštųjų mokyklų studentų migracinę patirtị.

Tyrimo metodai: mokslinès literatūros analizè, anketinè apklausa, statistinè duomenų analizè.

\section{Empirinio tyrimo metodologija ir metodika}

Emigruojančio akademinio jaunimo socialinių ryšių darbo ir edukacinejje paieškos strategijose tyrimas yra grindžiamas: 
- migracijos tinklo teorija, kuri siekia paaiškinti santykius tarp migruojančiojo asmens ir jo šeimos, draugų, likusių gimtojoje šalyje bei ryšius, apimančius keitimąsi informacija, finansinę pagalbą, pagalbą randant darbą, dalijantis patirtimi ir kt. tikslo šalyje. Migracijos srautai migracijos tinklo teorijoje traktuojami kaip save generuojantis procesas: atvykèliai įsikuria tam tikrose teritorijose, dirba tam tikruose darbo rinkos sektoriuose, sukuria tam tikrus kontaktus su aplinka, taip sukurdami socialini tinklą, kuris skatina ir kitus tautiečius vykti į tą šalị bei padeda naujiems imigrantams susirasti darbą, gyvenamąją vietą, suteikia reikalingą informaciją, o tai palengvina ir paspartina jų adaptaciją (Gurak, Caces, 1992; Massey ir kt., 1993; Zlotnik, 2006);

- socialiniu tinkly koncepcija, kuri socialinị žmonių elgesị aiškina remiantis ryšių tarp grupès narių bruožais, o socialinị tinklą apibrěžia kaip daugiau ar mažiau patvarias struktūras, apjungiančias individus i didelius tinklus. Viena vertus, socialinių tinklų koncepcija sudaro galimybes tirti, kaip socialinis tinklas funkcionuoja, kaip jis socialiai konstruojamas, kaip keičiasi laiko ir erdvès atžvilgiu, kita vertus - analizuoti socialinių veikejjų pozicijas tinkle, jų galimybes prisijungti prie kitu tinklų ir kt., nes migruojančiam individui heterogeniški socialiniai tinklai (giminystès, draugystès, kolegiški, kaimynystès) bei juose pasitikejjimu ir tarpusavio įsipareigojimais grịsti socialiniai ryšiai tampa vienu iš esminių išgyvenimo ir adaptacijos tikslo šalyje veiksnių (Mitchell, 1969; Coleman, 1988; Putnam, 1993; Palloni ir kt., 2001; Pescosolido, 2006);

- migracijos sistemu teorija, kuri migracijos procesą aiškina kaip makro ir mikro struktūrų dviejose teritorijose sąveikos išdavą. Makro struktūromis laikomi instituciniai veiksniai, mikro struktūros pačių emigrantų ìsitikinimai, patirtys, tinklai. Šie du lygmenys suprantami kaip konkrečių sąlygų šalyje visuma, o jų sąveika dažnai persidengia, todèl sunku juos išskirti bei konkrečiai įvardinti. Be to, šie lygmenys yra susipynę ir jungiasi tarpusavyje ivvairiais tarpiniais mechanizmais, kuriuos praktikoje identifikuoti ir pamatuoti jų poveikio intensyvumą dažnai neįmanoma (Mabogunje, 1970; Zlotnik, 2006);

- sprendimu priémimo teorija, kuri remiasi keturiais veiksniais, lemiančiais sprendimą migruoti ar ne: teigiami ir neigiami veiksniai, susiję su kilmès vietove ir tikslo šalimi (įdarbinimo galimybès, gyvenimo sąlygos), intervencinès kliūtys (fizinès, asmeninès), asmeniniai veiksniai (žinios, ¡žvalgumas). Sprendimų prièmimo teorija iškelia dvi prielaidas: pirma, ši teorija yra tinkama tuomet, kai individai gali laisvai priimti sprendimus, antra, sprendimas migruoti grindžiamas racionalumo principu: individai aiškiai žino ir suvokia savo tikslus ir siekius, juos formuluoja ir pasirenka tikslų siekimo būdus (Lee, 1966; Daugherty, Kammeyer, 1995; Srivastava, 1995);

- motyvacine migracijos sprendimy teorija, kurią sudaro keturi sprendimo prièmimo žingsniai: galimybè, išreiškianti pasirinkimo migruoti potencialumą (fizine ir psichologine prasme); motyvas, išryškinantis individo vertybes (ekonominè, socialinė gerovè); lūkesčiai, siejami su migracija, padèsiančia individams pasiekti išsikeltus tikslus (užsidirbti, sukurti šeimą); paskata, suvokiama kaip veiksniai teigiamai ar neigiamai veikiantys tikslų pasiekimą. Remiantis pastaraja teorija ir pabrèžiant motyvų bei paskatų svarbą, tarp jų išryškejja du pagrindiniai veiksniai, turintys ittakos migraciniam sprendimui ekonominiai ir šeiminiai (Sell, DeJong, 1978; Daugherty, Kammeyer, 1995); 
- žmogiškojo kapitalo teorija, kurioje pristatoma išsimokslinimo, amžiaus bei sveikatos svarba priimant sprendimą emigruoti. Remiantis šia teorija, igijusiems aukštajị išsilavinimą gimtojoje šalyje ir ketinantiems emigruoti individams atsiveria didesnès įsidarbinimo, igytų žinių, igūdžių pritaikymo ir realizavimo galimybès užsienio darbo rinkoje, todèl šie individai greičiau atgauna patirtas migracijos išlaidas. Be to, kuo individo sveikatos būklè yra geresnè, tuo labiau jis gali būti linkęs emigruoti, nes kitu atveju yra sunku susigrąžinti migracijos investicijas. Amžiaus veiksnys atskleidžia, kad kuo jaunesnis individas, tuo labiau jis gali būti linkęs emigruoti, nes lengviau prisitaiko prie naujos aplinkos, nèra susaistytas itin stiprių šeiminių ryšių (Dalen, Henkens, 2008).

Siekiant identifikuoti emigruojančio akademinio jaunimo socialinius ryšius darbo ir edukacinès paieškos strategijose, parengta akademinio jaunimo emigracinès patirties ir ketinimo emigruoti vertinimo metodika, kuri apima du diagnostinius blokus (darbo paieškos ir mokymosi strategijos tikslo šalyje).

Pirmasis diagnostinis blokas (darbo paieškos strategija tikslo šalyje) sudarytas iš 4 kriterijų, kurių pagalba buvo siekiama išsiaiškinti darbo pobūdị svečioje šalyje; veiksmus, atliktus išvykstant dirbti; motyvus išvykti dirbti ì pasirinktą šalį/šalis; pasitenkinimą darbu svečioje šalyje.

Antrajj diagnostini bloką (mokymosi paieškosstrategijatikslo šalyje) taip pat sudaro 4 kriterijai, kurių pagalba buvo siekiama išsiaiškinti mokymosi pobūdị svečioje šalyje; veiksmus, atliktus išvykstant mokytis; motyvus išvykti mokytis i pasirinktą šalì/šalis; pasitenkinimą mokymusi svečioje šalyje.

Pasirinktas tyrimo duomenų rinkimo metodas - anketine apklausa. Apklausai atlikti parengtas apklausos instrumentas
- klausimynas Lietuvos aukštųjų mokyklų studentams, kuris buvo konstruojamas remiantis mokslininkų (Repečkienè ir kt., 2009; Kvedaraitè ir kt., 2010; Repečkienė, Kvedaraite, 2011) atliktais tyrimais bei paskelbtais rezultatais.

Apklausos rezultatų analizei taikytas statistinès analizès metodas - aprašomoji statistika, kurios pagrindu atliktas pirminis kiekybinių duomenų apdorojimas. Matematinè statistinè analizė atlikta SPSS 19 for Windows (Statistical Package for Social Sciences) programine įranga.

Straipsnyje remiamasi projekto „Aukštụjų mokyklų studentų migracinę patirtị reprezentuojančių nuostatų tyrimas" rezultatais.

Tyrimo, organizuoto $2011 \mathrm{~m}$. kovolapkričio mèn., tikslinè grupè - Lietuvos aukštųjų mokyklų (universitetų ir kolegijų) studentai, studijuojantys laipsnị suteikiančiose studijose. Tyrimo imtis - 1187 Lietuvos aukštųjų mokyklų studentai.

Tyrimo dalyviu sociodemografinès charakteristikos. Tyrime dalyvavo $69 \%$ moteru ir $31 \%$ vyrų. Didžioji dauguma (53\%) yra 17-21 metų, 39 \% - 22-27 metų amžiaus studentai. Nustatyta, kad didžioji dalis yra nesukūrę šeimos (78 \%), neturi vaikų (90\%). Tik nedidelè dalis studentų (10\%) savo šeiminę padètị ịvardijo kaip vedęs/ištekejusi ir turintys vaikų (10\%).

Kaip svarbus socialinis rodiklis aiškinantis daugumos studentų migracinị aktyvumą yra jų šeimos (ar asmeninè) materialinè padètis. Nustatyta, jog daugumos studentų (40 \%) mènesinès pajamos yra mažos ir siekia iki 800 Lt per mènesi (atitikmuo - ES valiuta: $230 €$ ), taip pat dauguma (72 \%) jų nedirbo.

Tyrimo rezultatai atskleidè, jog vyrai turi daugiau migracijos ị užsienio šalis patirties nei moterys, ir kaip išvykimo tikslą nurodo darbą užsienyje. 
Analizuojant studentų amžių nustatyta, kad ị užsienį dirbti linkę išvykti 17-27 m. amžiaus studentai, kurie kilmés šalyje dirbo paslaugų (prekybos, švietimo, statybos, viešbučiai ir restoranai) sektoriuose. Remiantis 2010 m. Lietuvos statistikos departamento duomenimis, šiuose sektoriuose mokama minimali ménesinè alga (800 Lt, atitikmuo ES valiuta: $230 €$ ), todèl vyraujantis žemas darbo užmokestis veikia kaip ekonominė paskata studentus išvykti i tikslo šalis.

\section{Empirinio tyrimo rezultatai}

Nors klausimas „išvažiuoti ar likti?“, kurị užduoda sau kiekvienas emigruojantis, yra fundamentalus, tačiau išvykstančiajam itin svarbi socialinè ir ekonominè su persikèlimu ì tikslo šali susijusi informacija, kurią gali suteikti migracijos procese dalyvaujantys individai. Migrantas, būdamas socialinio tinklo veikeju, pats tampa informacijos šaltiniu ir prieiga kitiems naudotis tik jiems prieinamais tinklo ištekliais, resursais, galimybèmis. Anot D. S. Massey ir F. G. Espana (1987), migrantų tinklai apibrèžiami kaip socialinių ryšių voratinklis (raizginys), kuris padeda sumažinti tarptautinio mobilumo kaštus. Kiekvienas individas tapęs migrantu sumažina migracijos kaštus dẻka draugų ir giminaičiu rinkinio, kuris paskatina migruoti ir toliau plèsti tinklą.

Darbo paieškos strategija. Analizuojant akademinio jaunimo migracinę patirtí, nustatyta, kad didžioji jų dalis išvyko ị užsienio šalis darbo tikslais (32,6 \%), nors daugumos jų buvimas tikslo šalyse buvo trumpalaikis (nuo 3 mèn. iki 1 metų). Be to, akademinis jaunimas dirbo paslaugu sektoriuje: $26,5 \%$ - viešbučiuose ir restoranuose bei 9,5\% - prekyboje, tuo tarpu
$16,4 \%$ jaunimo buvo užimti žemès ūkio ir $10,6 \%$ pramonès sektoriuose.

Anot M. Boyd (1989), socialiniai ryšiai padeda emigrantams susirasti darbą, gyvenamają vietą, gauti informaciją, kontaktus, psichologinę paramą ar patarimus. Be to, šie ryšiai itin svarbūs žemesnès kvalifikacijos ar išsimokslinimo lygio darbuotojams, kurie pasižymi mažesniais adaptaciniais ištekliais, teigia A. Kazlauskienè ir L. Rinkevičius (2006b). Socialiniais ryšiais gaunama informacija apie galimybes dirbti užsienyje yra ypač svarbi studentams priimant sprendimą emigruoti, o susiejantys ryšiai pagal homogeniškumo požymi (pvz., etninę grupę, amžių, socialinę klasę) su kitoje šalyje gyvenančiais - studentus daro dar labiau mobilesnius.

Nustatyta, jog akademiniam jaunimui issidarbinti tikslo šalyse padejo tiek formalūs, tiek neformalūs ryšiai, tačiau pastarieji, būdami atviresni ir apimantys platesnị socialinị ratą, buvo svarbesni. Anot M. Granovetter (1983), stipriais ryšiais grindžiami santykiai yra tarp šeimos narių ir draugų, silpnais - tarp pažistamų. Šeimos narių, draugų bei giminaičių parama buvo svarbesnè 17-27 metų amžiaus jaunimui. Kad draugai yra svarbūs migracinio tinklo veikèjai, pažymèjo 17-21 ir 22-27 metų amžiaus akademinis jaunimas (atitinkamai 18,8 \% ir 16,8\%), nurodydami juos kaip potencialius paramos išteklius išvykstant dirbti ị tikslo šalị. Draugų ir giminaičių gyvenančių užsienio šalyse teikiama parama yra aktuali tiek bakalauro (atitinkamai 16,1\% ir 14,6\%), tiek magistro studijas (atitinkamai 29,7 \% ir 18,9\%) pasirinkusiems aukštųjų mokyklų studentams, vis dèlto svarbesnè ji buvo antrosios pakopos studentams.

Nors draugu parama yra tiek pat aktuali vyrams ir moterims, tačiau santykiai su šeimos nariais, kurie dažniausiai būna 
paremti artumo, emocinio intensyvumo ir pagalbos lūkesčiais, yra svarbesni studentèms moterims nei studentams vyrams. Kadangi didžioji dalis tyrime dalyvavusių studentų $(78 \%)$ yra nesukūrę savo šeimos, tai stipriais ryšiais grindžiami santykiai su šeimos nariais, šiuo atveju - tèvais, broliais ir/ar seserimis, yra labiau svarbūs pirmosios pakopos studentams (15,3\%).

Be to, išvykę dirbti ị užsienị 17-21 metų ir 22-27 metų amžiaus studentai įsidarbino pasitelkdami ir formalius ryšius: ịdarbinimo agentūras Lietuvoje (atitinkamai $13,8 \%$ ir 16,8\%), kreipési tiesiai ị darbdavi (atitinkamai $11,3 \%$ ir 7,9\%) ar gavo darbo pasiūlymą tiesiai iš darbdavio (atitinkamai $7,5 \%$ ir $13,9 \%)$.

Nors stiprūs draugystès ryšiai yra laikomi mažiau efektyvia priemone prieinant prie informacijos ir išteklių (Granovetter, 1983; Putnam, Goss, 2002), tačiau tyrime dalyvavę respondentai informacijos apie pageidaujamą darbą tikslo šalyse visgi ieškojo draugų (28 \%) ir šeimos narių (17\%) rate. Nors respondentai tarpasmeniniais tinklais taip pat ieškojo ir informacijos apie gyvenamają vietą tikslo šalyse, tačiau reikšmès turejo ir formalūs ryšiai, t. y. net vidutiniškai $35 \%$ studentų gyvenamąją vietą suteikè darbdavys tikslo šalyje. Socialiniame gyvenime sujungiantys ryšiai (angl. bridging), anot R. Žiliukaitès (2004), padeda individams judèti i prieki, todèl atsiranda stipresne paskata studentams emigruoti darbo tikslais.

Kaip svarbų informacijos šaltinį ir išteklių ieškant pageidaujamo darbo respondentai pažymejjo internetą. Internetas buvo reikšmingas tiek 17-21 ir 22-27 metu amžiaus (atitinkamai $23 \%$ ir $28 \%$ ) studentams, tiek respondentams - vyrams ir moterims (atitinkamai $27 \%$ ir $24 \%$ ), tiek pirmos ir antros studiju pakopos studentams (atitinkamai $25 \%$ ir $30 \%$ ). Tačiau internetas kaip informacijos šaltinis gyvenamajai vietai susirasti emigracinę patirti turinčių studentu tarpe buvo vertinamas kaip mažiau reikšmingas. R. Žiliukaitė (2004), nagrinèdama socialinio kapitalo dinamiką, teigia, kad socialiniam kapitalui poveikị gali turèti spartus informacinių technologiju - kompiuteriu, interneto skverbimasis ị individų kasdienị gyvenimą bei ypač pastarojo panaudojimo sritys. Interneto poveikis socialiniam kapitalui mokslininku tarpe vertinamas nevienareikšmiškai, dažnai pabrèžiamas jo neigiamas aspektas socialinių santykių aspektu: bendruomeniškumo praradimas, retesnis bendravimas su šeimos nariais, santykių su šalia (vietos atžvilgiu) gyvenančiais žmonèmis silpnëjimas (Nie, Erbring, 2000; Norris, 2003). Viena vertus stipriais ryšiais palaikomi santykiai su šeimos nariais ir draugais iškeičiami ị silpnus ryšius, kurie, anot M. Granovetterio (1983), suteikia didesnę prieigą prie informacijos ieškant darbo, gyvenamosios vietos ar išteklių. Kita vertus, internetas susieja individus pagal panašumo požymius (pvz., socialinius, interesus, veiklą) ir naudojamas susietajam (angl. bonding) socialiniam kapitalui formuoti ir palaikyti (Uslaner, 2000; Norris, 2003; Žiliukaité, 2004). Visgi, reikia kalbèti apie socialinių ryšių transformaciją, kurią palengvino internetas, suteikdamas individams daugiau galimybių bendrauti ir gauti ìvairiapusiškos informacijos, taip juos suartindamas ir praplèsdamas jų socialinius tinklus. Taigi, akademinis jaunimas internetą vertina ne tik kaip bendravimo kanalą ir bendradarbiavimo formą, bet kaip pagalbą igyvendinant savo tikslus (veiklas) mažesnemis sąnaudomis, t. $y$. mažinant emigravimo kaštus.

Analizuojantstudentų emigracinępatirtị tikslo šalyje, nustatyta, kad jų tarpasmeninis tinklas (šeima, draugai, giminès, kolegos ir 
pažĭstami) mažai lèmė jų išvykimą dirbti ị užsienio šali vertinant tiek pagal amžių, lyti ar studijų pakopą (1 lentelè).

Tačiau materialinès gyvenimo sąlygos ir darbo užmokestis veike kaip pritraukiantieji tikslo šalyse veiksniai tiek jauno (17-27 m.) ar vyresnio (22-27 m.) amžiaus studentus, tiek vyrus ar moteris. Galimybe ìsidarbinti pagal igytą profesiją nebuvo svarbus veiksnys, paskatinęs juos išvykti dirbti ị užsienio šalị. Taigi, dirbdami paslaugų sektoriuje akademinis jaunimas buvo patenkintas darbu tikslo šalyse (77 \%) ir norètų dar sugrịžti dirbti ị šią šalị.

Vertinant akademinio jaunimo ketinimus emigruoti, tyrimo rezultatai pasiskirste sekančiai: $39 \%$ jų ketina išvykti i užsieni ir tiek pat - nevykti. Dažniausiai studentų pasirenkamos tikslo šalys yra Jungtinè Karalystė, Airija, Ispanija, Vokietija ir JAV, ị kurias jie ketina išvykti dirbti ilgesniam laikotarpiui (70 \%), t. y. ilgiau nei metams. 17-21 metú amžiaus respondentai issidarbinant tikslo šalyse ketina labiau naudotis tarpasmeniniais tinklais (draugais $-32 \%$, giminaičiais $-21 \%$ ), tuo tarpu 22-27 m. amžiaus - instituciniais tinklais (kreipsis ị ịdarbinimo agentūrą - $13 \%$ ir tiesiai ị darbdavi $-18 \%$ ) ir tarpasmeniniais (draugais - $25 \%$ ). Kaip potencialius išteklius darbinimosi procese studentai (moterys ir vyrai) vertina draugus (atitinkamai $29 \%$ ir $26 \%$ ), tačiau studentai vyrai papildomai išskiria darbdavị (20 \%) užsienio šalyje, ị kurią ketinama vykti.

Studentų gebejimai naudotis informacinėmis technologijomis, ypač integruojant interneto galimybes i savo veiklas, parodo jų siekį formuoti savo socialinị kapitalą ir didinti ịvairias kapitalo rūšis. Nustatyta, jog 17-21 metų ir ypač 22-27 metu amžiaus ketinantis emigruoti akademinis jaunimas internetą naudojo kaip informacijos šaltinį ieškant darbo (atitinkamai $30 \%$ ir $44 \%$ ) ir gyvenamosios vietos (atitinkamai $18 \%$ ir $38 \%$ ). Be to, antros pakopos studentai (58\%) ir respondentai vyrai (52 \%) yra labiau linkę ieškoti darbo internetu nei pirmos pakopos studentai ir respondentès moterys (atitinkamai abu po $32 \%)$. Tenka pastebèti, kad pirmos pakopos studentams svarbi yra tarpasmeninio tinklo narių, ypač draugu ir giminaičių, teikiama parama ieškant darbo ar gyvenamosios vietos tikslo šalyse.

Vertinant ketinimo išvykti dirbti i tikslo šalis veiksnius, nustatyta, jog 17-21 ir 22-27 m. amžiaus aukštųjų mokyklų

Veiksniai lèmę akademinio jaunimo išvykimą dirbti ị užsienio šalị (\%)

1 lentelè

\begin{tabular}{|l|c|c|c|c|c|c|c|}
\hline \multirow{2}{*}{\multicolumn{1}{|c|}{ Veiksniai }} & \multicolumn{2}{c|}{ Amžius } & \multicolumn{2}{c|}{ Lytis } & \multicolumn{3}{c|}{ Studiju pakopa } \\
\cline { 2 - 9 } & $17-21$ & $22-27$ & Vyras & Moteris & Pirma & Antra & Trečia \\
\hline Šeima & 33,8 & 40,6 & 32,7 & 38,0 & 38,0 & 32,4 & 14,3 \\
\hline Giminés & 17,5 & 14,9 & 7,7 & 19,0 & 16,8 & 16,2 & - \\
\hline Draugai & 32,5 & 32,7 & 26,9 & 34,3 & 33,6 & 27,0 & 14,3 \\
\hline Kolegos & 4,0 & 5,9 & 5,8 & 5,8 & 4,4 & 5,4 & 28,6 \\
\hline Materialinės gyvenimo sąlygos & 68,8 & 82,2 & 71,2 & 77,4 & 73,7 & 83,8 & 71,4 \\
\hline Darbo užmokestis & 83,8 & 85,1 & 84,6 & 83,9 & 84,7 & 83,8 & 57,1 \\
\hline Nedarbas & 35,0 & 55,4 & 44,2 & 46,7 & 42,3 & 59,5 & 28,6 \\
\hline Isidarbinimo galimybės ateityje & 38,8 & 46,5 & 50,0 & 40,1 & 43,1 & 32,4 & 71,4 \\
\hline Galimybé įidarbinti pagal profesiją & 13,8 & 24,8 & 26,9 & 17,5 & 16,8 & 18,9 & 85,7 \\
\hline Karjeros perspektyvos & 25,0 & 36,6 & 38,5 & 30,7 & 30,7 & 27,0 & 85,7 \\
\hline
\end{tabular}


studentams poveikị turèjo: asmeniniai (šeima, draugai), ekonominiai (materialinès gyvenimo sąlygos, darbo užmokestis, nedarbas), profesiniai (įsidarbinimo galimybès ateityje, karjeros perspektyvos, galimybè ịsidarbinti pagal profesiją) motyvai (2 lentelè).

Iš politinių veiksnių 17-21 ir 22-27 m. akademiniam jaunimui ketinimui išvykti turèjo ịtakos šalies kultūrinis patrauklumas (atitinkamai po $42 \%$ ), šalies socialinès apsaugos sistema (atitinkamai $55 \%$ ir 66 $\%$ ), šalies mokesčių sistema (atitinkamai $51 \%$ ir $57 \%$ ), šalies darbo rinka (atitinkamai $56 \%$ ir $67 \%$ ). Ketinimas emigruoti yra sąmoningas ir tikslingas individo pasirinkimas, veikiamas ịvairių individą ittakojančių veiksnių: nuo asmeninių, profesinių iki sociokultūrinių, politinių ir ekonominių. Pastarieji ir ypač darbo užmokestis yra svarbus akademinio jaunimo išvykimą lemiantis veiksnys, nes, kaip rodo tyrimo rezultatai, jie tikslo šalyse ketina dirbti bet kokị darbą, svarbu - uždarbis (56\%). Deja, tik $26 \%$ apklaustųjų ketina dirbti darbą atitinkantị jų igyjamą profesiją. Taigi, akademinio jaunimo ketinimą emigruoti veikiantys veiksniai jų priimami kaip prisitaikymo prie kintančios išorinès aplinkos strategija ir suvokiama kaip individualių sprendimų pasekmè.

Edukacinès paieškos strategija. Europos Sajunga propaguoja mokymosi visą gyvenimą idejją, socialinio dialogo stiprinimą, aktyvių darbo rinkos priemonių diegimą, modernios gerovès valstybès kūrimą, orientuojantis i aukštos kvalifikacijos specialistų, ypač akademinio jaunimo, mobilumą (Docquier, Marfouk, 2004).

Ištyrus Lietuvos aukštųjų mokyklų studentų emigracinę patirti edukacijos procesuose, pastebèta, kad nors ị užsieni studijuoti išvyko nedidelè dalis (tik $6 \%$ ), tačiau daugiausia jų 2009 ir 2010 metais išvyko i Europos Sajungos (JK, Airija, Švediją, Vokietija) ir ne Europos Sąungos (Turkiją, JAV, Kanada) šalis. Išvykusieji daugiausia mokèsi universitete (51 \%) ir kolegijose (32\%).

Studentai išvyko studijuoti ị tikslo šali dèl profesinių, ekonominių veiksnių: įsidarbinimo galimybių užsienyje, karjeros perspektyvų, stipendijų (3 lentelè).

Iš politinių motyvų grupès, skatinančius respondentus studijuoti užsienio aukštosiose mokyklose, jauno (17-21 m.) ir vyresnio (22-27 m.) amžiaus respondentai pažymèjo šalies kultūrinị patrauklumą

Veiksniai lèmę akademinio jaunimo ketinimą išvykti dirbti ị užsienio šalị (\%)

2 lentelè

\begin{tabular}{|l|c|c|c|c|c|c|c|}
\hline \multirow{2}{*}{ Veiksniai } & \multicolumn{2}{c|}{ Amžius } & \multicolumn{2}{c|}{ Lytis } & \multicolumn{3}{c|}{ Studiju pakopa } \\
\cline { 2 - 8 } & $17-21$ & $22-27$ & Vyras & Moteris & Pirma & Antra & Trečia \\
\hline Šeima & 49,2 & 62,0 & 49,3 & 56,5 & 55,9 & 57,6 & 37,5 \\
\hline Giminės & 19,5 & 18,2 & 17,4 & 18,8 & 18,3 & 15,2 & 12,5 \\
\hline Draugai & 42,2 & 33,1 & 24,6 & 41,9 & 37,1 & 39,4 & 25,0 \\
\hline Kolegos & 15,6 & 10,7 & 7,2 & 14,7 & 12,4 & 12,1 & 25,0 \\
\hline Materialinės gyvenimo sąlygos & 87,5 & 89,3 & 81,2 & 90,6 & 87,6 & 90,9 & 87,5 \\
\hline Darbo užmokestis & 94,5 & 95,9 & 91,3 & 96,3 & 94,6 & 97,0 & 87,5 \\
\hline Nedarbas & 71,1 & 80,2 & 68,1 & 78,0 & 75,2 & 72,7 & 75,0 \\
\hline Isidarbinimo galimybės ateityje & 78,9 & 81,8 & 75,4 & 81,7 & 80,2 & 84,8 & 75,0 \\
\hline Galimybė ịsidarbinti pagal profesiją & 61,7 & 62,0 & 68,1 & 60,2 & 59,4 & 81,8 & 87,5 \\
\hline Karjeros perspektyvos & 68,0 & 75,2 & 75,4 & 71,9 & 68,3 & 84,8 & 100,0 \\
\hline
\end{tabular}


Akademinị jaunimą išvykti studijuoti ị užsienio šalį lemiantys veiksniai (\%)

\begin{tabular}{|l|c|c|c|c|c|c|c|}
\hline \multirow{2}{*}{ Veiksniai } & \multicolumn{2}{|c|}{ Amžius } & \multicolumn{2}{c|}{ Lytis } & \multicolumn{3}{c|}{ Studiju pakopa } \\
\cline { 2 - 9 } & $17-21$ & $22-27$ & Vyras & Moteris & Pirma & Antra & Trečia \\
\hline Šeima & 26,7 & 20,8 & 40,0 & 19,4 & 20,7 & 33,3 & 33,3 \\
\hline Giminės & 26,7 & 4,2 & 20,0 & 9,7 & 10,3 & 16,7 & 16,7 \\
\hline Draugai & 46,7 & 33,3 & 40,0 & 35,5 & 41,4 & 33,3 & 16,7 \\
\hline Kolegos & 13,3 & 16,7 & 20,0 & 18,9 & 17,2 & 16,7 & - \\
\hline Materialinės gyvenimo sąlygos & 46,7 & 20,8 & 40,0 & 25,8 & 27,6 & 33,3 & 33,3 \\
\hline Darbo užmokestis & 26,7 & 20,8 & 50,0 & 19,4 & 24,1 & - & 66,7 \\
\hline Nedarbas & 13,3 & 4,2 & - & 9,7 & 6,9 & - & 16,7 \\
\hline Isidarbinimo galimybės užsienyje & 73,3 & 58,3 & 50,0 & 64,5 & 65,5 & 33,3 & 66,7 \\
\hline Stipendija & 60,0 & 50,0 & 60,0 & 48,4 & 58,6 & 33,3 & 33,3 \\
\hline Studijų kaina & 40,0 & 33,3 & 50,0 & 29,0 & 34,5 & 33,3 & 33,3 \\
\hline Galimybe įsidarbinti pagal specialybę & 66,7 & 54,2 & 50,0 & 61,3 & 58,6 & 33,3 & 83,3 \\
\hline Karjeros perspektyvos & 73,3 & 66,7 & 60,0 & 74,2 & 72,4 & 50,0 & 83,3 \\
\hline
\end{tabular}

(atitinkamai $80 \%$ ir $83 \%$ ), šalies saugumą (atitinkamai $40 \%$ ir $42 \%$ ), šalies mokslo sistemą (atitinkamai $47 \%$ ir $63 \%$ ). Tuo tarpu vertinant pagal lytị, moterų ir vyrų respondentų pasirinkimą studijuoti užsienio aukštojoje mokykloje daugiausia lèmé ekonominiai veiksniai: materialinès gyvenimo sąlygos, darbo užmokestis ir stipendijos dydis.

Socialinis kapitalas siejamas su visomis gyvenimo pusèmis ir veiklomis, gyvenimo ir ekonominio mąstymo bei elgesio būdais, todèl jo supratimas yra svarbus daugialypio turinio praktikoje (Tuomi, 2003; Augustinaitis, 2004). Remdamasis savo socialiniu kapitalu individas akumuliuoja profesinius, edukacinius, technologinius ir kitus aspektus, kuriuos jis panaudoja priimdamas ịvairius sprendimus, vieną iš jų - kurios šalies ir kokioje aukštojoje mokykloje studijuoti. Tyrimo rezultatų analizè atskleidè, kad dauguma akademinio jaunimo naudojosi instituciniais ryšiais siekdami studijuoti užsienio aukštojoje mokykloje. Dauguma studentų vyko trumpalaikèms studijoms (nuo 5 iki 10 mèn.) pagal studentų mainų programas, mokèsi universitete ir gavo studijas liudijančius dokumentus (diplomus - $22 \%$, sertifikatus - $17 \%$, kvalifikacijos pažymèjimus $15 \%)$.

Vertinant studentų akademini mobilumą ypač yra aktualūs informaciją apie profesines galimybes teikiantys ir profesinius interesus tenkinantys ryšiai (Palioni ir kt., 2001). Tyrime paaiškèjo, jog studijuoti ì užsieni vykę respondentai kaip informacijos šaltiniu naudojosi: internetu, mokslo institucijų bei studijų mainų programos koordinatoriaus teikiama informacija ir parama. Pastarieji ryšiai ypač reikšmingi buvo jaunesnio amžiaus (17-21 m.) studentams (30\%). 17-21 metų amžiaus (30\%) respondentai informacijos apie pageidaujamą mokymosi instituciją užsienio šalyse taip pat ieškojo pasitelkdami plačiausiai naudojamą žinių išteklių - internetą. Tuo tarpu tarpasmeniniais tinklais (šeimos, giminių ir pažistamų) gaunama informacija, parama studijoms užsienio šalyse studentai nesinaudojo. Tyrimas parodè, kad informacijos apie gyvenamąą vietą tikslo 
šalyje respondentams suteikè pati aukštoji mokykla (vidutiniškai $50 \%$ ), todèl tik nedaugelis studentų papildomai pasitelkè kitus žinių šaltinius, t. y. spaudą, internetą. Taigi, užsienio šalyse studijavę studentai yra patenkinti studijomis ir norètų toliau studijuoti užsienio šalyse (81\%).

\section{Išvados}

Tyrime nustatyta, kad Lietuvos aukštųjų mokyklų studentai svarbiausiais socialiniais ryšiais darbo paieškos užsienio šalyse ìvardijo tarpasmeninius (neformalius). Nors įdarbinimo agentūros yra kaip informacijos teikimo ir darbo, gyvenamosios vietos užsienyje žinių šaltinis, tačiau dauguma respondentų informaciją apie įsidarbinimo galimybes užsienio šalyse gavo iš artimiausios aplinkos (šeimos ir draugų). Studentai, pasirinkę mokymosi užsienio šalyse strategiją, kaip reikšmingiausius socialinius ryšius įvardijo institucionalizuotus, kurių svarba išryškejjo ieškant reikalingos informacijos apie mokymosi institucijas ir gyvenamąą vietą.

Tyrimą finansavo Lietuvos mokslo taryba (sutarties Nr. MIP-38/2010).

\section{Literatūra}

1. Antinienė, D., Baršauskienè, V., Merkys, G. (2004). Lietuvos studentų socialiniai ryšiai: diagnostinis tyrimas naudojant socialinio tinklo matricą // Psichologija. Nr. 30.

2. Augustinaitis, A. (2004). Šiuolaikinio žinojimo sandara // Informacijos Mokslai. T. 29.

3. Boyd, M. (1989). Family and Personal Networks in International Migration: Recent Development and New Agendas // International Migration Review. Vol. 23, No. 3.

4. Bourdieu, P. (1977). Cultural Reproduction and Social Reproduction / In Power and Ideology in Education, ed. J. Karabel and A. H. Halsey. - New York: Oxford University Press.

5. Bourdieu, P. (1986). The Forms of Capital / In Handbook of Theory and Research for the Sociology of Education, ed. J. G. Richardson. - New York: Greenwood Press.

6. Bučaitè-Vilkè, J., Rosinaite, V. (2010). Tarpasmeninių ryšių tinklo formavimasis ir jo reikšmé migracijoje // Kultūra ir visuomenè. Socialinių tyrimų žurnalas. Nr. 1 (2).

7. Coleman, J. (1988). Social Capital in the Creation of Human Capital // American Journal of Sociology. Vol. 94.

8. Dabartinès lietuvių kalbos žodynas: šeštas (trečias elektroninis) leidimas. Kompaktinè plokštelè / redaktorių kolegija: Stasys Keinys (vyr. redaktorius), Laimutis Bilkis, Jonas Paulauskas, Vytautas Vitkauskas. - Vilnius: Lietuvių kalbos institutas,
2006; internetinè versija, 2011. - <http://dz.lki.lt>.

9. Dalen, H. P. van, Henkens, K. (2008). Emigration Intentions: Mere Words or True Plans? Explaining International Migration Intentions and Behavior. - CentER Discussion Paper 2008-60. Prieiga per internetą: <http://www.nidi.knaw.nl/Content/ NIDI/output/2008/center-discussion-2008-60. pdf/>, [žiūrèta 201106 19]. doi: 10.2139/ ssrn.1153985.

10. Daugherty, H. G., Kammeyer, K. C. W. (1995). An Introduction to Population. 2nd edition. The Guilford Press: New York, London.

11. Docquier, Fr., Marfouk, A. (2004). Measuring the International Mobility of Skilled Workers (19902000): Release 1.0 (August 19,2004). - World Bank Policy Research Working Paper No. 3381. Prieiga per internetą: <http://www-wds.worldbank.org/ external/default/WDSContentServer/WDSP/ IB/2004/09/22/000160016_20040922150619/ Rendered/PDF/wps3381.pdf/>, [žiūrèta 201107 15]. doi: 10.1596/1813-9450-3381.

12. Gečienè, I. (2009). Socialinių tinklų analizé migracijos studijose // Sociologija. Mintis ir veiksmas. Nr. 2 (25).

13. Granovetter, M. (1973). The Strength of Weak Ties // American Journal of Sociology. Vol. 78. doi: $10.2307 / 2776392$.

14. Granovetter, M. (1983). The Strength of Weak Ties: a Network Theory Revisited // Sociological Theory, Vol. 1. doi: 10.2307/202051. 
15. Gurak, D. T., Caces, F. (1992). Migration Networks and the Shaping of Migration Systems / In International Migration Systems: A Global Approach, ed. M. Kritz, L. L. Lim and H. Zlotnick. - Oxford: Clarendon Press.

16. Hanneman, R. A. (2001). Introduction to Social Network Methods. Prieiga per internetą: <http:// faculty.ucr.edu/ hanneman/>, [žiūrèta 20111122 ] .

17. Kazlauskienè, A., Rinkevičius, L. (2006a). Lithuania "Brain Drain" Causes: Push and Pull Factors // Engineering Economics. Vol. 1, No. 46.

18. Kazlauskienè, A., Rinkevičius, L. (2006b). The Role of Social Capital in the Highly-Skilled Migration from Lithuania // Engineering Economics. Vol. 4, No. 49.

19. Kvedaraitė, N., Žvirelienè, R., Repečkienė, A. (2010). Research of Economic Migration Reasons of University Students // Mokslas ir edukaciniai procesai $=$ Science and Processes of Education. Vol. 1, No. 10, T. 2.

20. Lee, E. S. (1966). A theory of migration // Demography. Vol. 3, No. 1.

21. Lin, N. (2001). Building a Network Theory of Social Capital / In Social capital - Theory and Research, ed. N. Lin, K. Cook and R. S. Burt. New York, NB: Transaction Publishers.

22. Mabogunje, A. L. (1970). Systems Approach to a Theory of Rural - Urban Migration // Geographical Anglysis. Vol. 2, No. 1. doi: 10.1111/ j.1538-4632.1970.tb00140.x.

23. Massey, D. S., Arango, J., Hugo, G., Kouaouci, A., Pellegrino, A., Taylor, J. E. (1993). Theories of International Migration: A Review and Appraisal // Population and Development Review. Vol. 19, No. 3. doi: 10.2307/2938462.

24. Massey, D. S., Espana, F. G. (1987). The Social Process of International Migration // Science Magazine. Vol. 237, No. 4816. doi: 10.1126/ science.237.4816.733.

25. Maslauskaitè, A., Stankūnienè, V. (2007). Šeima abipus sienų. Lietuvos transnacionalinès šeimos genezè, funkcijos, raidos perspektyvos. - Vilnius.

26. Merkys, G., Baršauskienè, V., Antinienè, D. (2004). Lietuvos studentų socialiniai ryšiai: diagnostinis tyrimas, naudojant socialinio tinklo matricą // Psichologija. Nr. 30.

27. Mitchell, J. C. (1969). The Concept and Use of Social Networks / In Social Networks in Urban Situations: Analyses of Personal Relationships in Central African Towns, ed. J. C. Mitchell. Manchester: The University Press. doi: 10.1525/ aa.1971.73.4.02a00970.
28. Nie, N., Erbring, L. (2000). Study Offers Early Look at How Internet is Changing Daily Life: Report. Prieiga per internetą: <http://news.stanford. edu/news/2000/february16/internetsurvey-216. html/>, [žiūrèta 20111208 ].

29. Norris, P. (2003). Social Capital and ICTs: Widening or Reinforcing Social Networks? Prieiga per internetą: <http://www.esri.go.jp/jp/ workshop/030325/030325paper6.pdf/>, [žiūrèta 20111127 ].

30. Palloni, A., Massey, D. S., Ceballos, M., Espinosa, K., Spittel, M. (2001). Social Capital and International Migration: a Test Using Information on Family Networks // The American Journal of Sociology. Vol. 106, No. 5. doi: 10.1086/320817.

31. Pescosolido, B. A. (2006). The Sociology of Social Networks / In The Handbook of 21st Century Sociology, ed. C. D. Bryant and D. L. Peck. - Thousand Oaks, CA, Sage Publications. doi: 10.4135/9781412939645.n20.

32. Portes, A. (1998). Social Capital: Its Origins and Applications in Modern Sociology // Annual Review of Sociology. Vol. 24. doi: 03600572/98/0815-0001\$08.00.

33. Putnam, R. (1993). Making Democracy Work: Civic Traditions in Modern Italy. - Princeton, NJ: Princeton University Press.

34. Putnam, R. D., Goss, K. A. (2002). Introduction / In Democracies in Flux: The Evolution of Social Capital in Contemporary Society, ed. R. D. Putnam. - Oxford University Press. doi: 10.1093/ 0195150899.001 .0001 .

35. Repečkienè, A., Kvedaraite, N. (2011). Student's Social Ties as a Knowledge Resource in the Process of Migration // KSI Transactions on Knowledge Society. Vol. 4, No. 3.

36. Repečkienè, A., Kvedaraitè, N., Žvirelienè, R. (2009a). External and Internal Migration Insights in the Context of Globalization: Higher School Graduates' Attitude // Economics and Management = Ekonomika ir vadyba. Vol. 14 .

37. Repečkienè, A., Žvirelienè, R., Kvedaraitè, N. (2009). Higher School Students Approach to Internal Migration: Practical Aspect. - Paper presented at the 2009 Changes in Social and Business Environment Conference, Panevėžys, November 4-5.

38. Schweizer, T., White, D. R. (1998). Revitalizing the Study of Kinship and Exchange with Network Approaches / In Kinship, Networks and Exchange, ed. T. Schweizer and D. R. White. Cambridge, NY: Cambridge University Press. doi: 10.1017/CBO9780511896620. 
39. Scott, J. (2001). Social Network Analysis: a handbook. - London: SAGE Publications.

40. Sell, R. R., DeJong, G. F. (1978). Toward a Motivational Theory of Migration Decision Making // Population \& Environtment. Vol. 1, No. 4. doi: 10.1007/BF00972555.

41. Sipavičienè, A. (2006). Tarptautinė gyventojų migracija Lietuvoje: modelio kaita ir situacijos analizè. Vilnius.

42. Srivastava, O. S. (1995). Demography and Population Studies. - Vikas Publishing House Pvt Ltd.

43. Tuomi, I. (2003). Social Capital in the Knowledge Society: Generation, Accumulation, and the Impact of ICTs. - Working paper draft. Institute for Prospective Technological Studies.
44. Uslaner, E. (2000). The Internet and Social Capital // Communications of the ACM (Annals of Computing Machinery). Vol. 43. doi: $10.1145 / 355112.355125$.

45. ertovec, S. (2002). Transnational Networks and Skilled Labour Migration. Prieiga per internetą: <http://www.transcomm.ox.ac.uk/working\%20 papers/WPTC-02-02\%20Vertovec.pdf/>, [žiūrèta $20111027]$.

46. Zlotnik, H. (2006). Theories of International Migration / In Demography: Analysis and Synthesis. A Treatise in Population Studies. Volume 2, ed. G. Caselli, J. Valtin and G. Wunsch. - Boston: Elsevier / Academic Press.

Straipsnis itteiktas: 20120918

Parengtas publikuoti: 20121201

\section{Nida KVEDARAITÉ, Aušra REPEČKIENĖ, Rasa GLINSKIENĖ \\ SOCIAL TIES OF EMIGRATING ACADEMIC STUDENTS IN THE DEVELOPMENT OF STRATEGIES FOR THE SEARCHING OF JOBS AND EDUCATION}

\section{S u $\mathrm{m}$ m a r y}

While being extensively applied in social sciences, analysis of social ties is increasingly more often invoked as a methodological approach in migration studies, when examining the diasporas, transnational ties and migrant networks. Interpersonal ties of migrants create a feeling of belonging, help them adapt and join a new society. Relationships based on family or kinship ties help the individuals to deal with the problems faced in everyday living; however, the key role of such relationships is to reduce different kinds of costs (financial, psychological) as well as risks associated with emigration. Institutionalised ties include relationships transpiring in the public space, which are invisible, but significant in the life of individuals: they enable the accessibility of material, information and other resources, whereas the function of the capital created through social ties is to create a network of interpersonal social relationships, which help achieving one's economic or social objectives, or amplify the financial capital.

The article analyses the importance of social relationships based on mutual trust between the emigrating individuals (in this case - academic students (of universities and colleges)), which is emphasised by the following problem questions: is the emigration experience of individuals affected by their ties with the family, relatives, friends, colleagues/acquaintances? How are the interpersonal and institutionalised ties rated in the strategies for searching of jobs/education of migrating individuals?

It was established that formal and informal ties help the academic students to find jobs in destination countries, but the latter ones, being more opened and encompassing a broader social circle, are more important. The support of family members, friends and relatives is more important to students aged 17-27 and studying in universities and colleges. In the opinion of respondents, friends are important players of the migration network and are rated as potential sources of support for those departing to work in the destination country. Their support is relevant to the academic students of Bachelor's as well as Master's studies; however, it is more important for those in graduate studies. Although the support of friends is similarly relevant to males and females, the relationships with family members, which are generally based on expectations of closeness, emotional intensity and help, are more important to female students than males. 
Analysing the emigration experience of students in the destination country, it was established that their interpersonal network (family, friends, relatives, colleagues and acquaintances) have little influence to their departure to work in a foreign country whether evaluating by age, gender or study level. Nonetheless, material conditions of living and salary operate as attracting factors in the countries of destination for students of different ages, males and females equally. The possibility to get employment according to the acquired speciality is not an important factor encouraging them to emigrate for work to a foreign country.

Assessing the emigration intentions of academic students it was established that only one third of them plan to go working abroad (mostly, to European Union (EU) countries) for more than one year. This decision was affected by personal (family, friends), economic (material conditions of living, salary, unemployment) and professional (future employment opportunities, career prospects, possibility to get a job according to one's profession) factors. 